\title{
The impact of direct-indirect taxation on consumer
}

\author{
Ezat Sabir Esmaeel \\ University of sulaimani Faculty of Economics and Administration
}

\begin{abstract}
One of the most important resources of revenue for every Government is tax which is fulfilling its commitments towards society. Taxes are classified as direct taxes and indirect taxes. Direct and indirect taxation have different impacts on the consumer, they have advantages and disadvantages in the same time. Direct taxation is equitable, certain and adverse effects can be avoided, in the same time it is unpopular, inconvenience and it is possible to evade by the tax payers. However, indirect taxation is the solution for the problem of externality and it gives the government more control over its use of fiscal policy because indirect taxes can be changed between budgets without parliamentary approval. In contrast, direct taxes can only be changed in the annual budget.
\end{abstract}

\section{INTRODUCTION}

Financing of the Government is important and universal concern. Governments in the most of the world have started number of public projects, such as social security, protection and other services of public utilities like electricity, water supply, railways, atomic energy. Public finance deals with the income and expenditures of public authorities. It deals with the financial operations or finances of the Central Government, State, Regional and Local government's revenues from various tax sources and non-tax sources.

Public expenditure is the central part of the study of public finance, which incurred by the Government for attainment of public good. Every Government has to maintain law and order armed forces for providing protection, public parks, schools, and health care of people. The importance of raising public revenue follows from the necessity of incurring public expenditure. As the modern Government has to perform several functions for the welfare of the people and like these functions require huge amount of expenditure. All governments collect taxes to fund public services. Taxes are the principal source of recurring revenue under government control, in all countries tax policy is at the heart of the political debate on the level of public services that should be provided and who should pay for them. The economic effects of taxation may be good as well as bad. Due to heavy imposition of tax, the ability of tax -payer to work may be affected adversely or he may be reluctant to work more since his additional income is taxed.

Direct taxation is defined as taxation imposed upon the person who is intended to be the final bearer of the burden of payment. Today's income tax is a form of direct taxation, which is to say the government levies the tax directly on individuals and businesses. Indirect taxation is defined as taxation imposed upon others than the person who is intended to bear the final burden. There has been a gradual shift away from direct towards indirect taxes. Increased indirect taxation has allowed the government to reduce the overall tax burden on income and capital.

Direct taxation is equitable for consumers because higher incomes are taxed more heavily and lower incomes slightly. Furthermore, direct taxes satisfy the condition of certainty because tax payer is certain as to how much he is expected to pay, and similarly the state is certain as to how much it has to receive income from direct taxes. Disadvantages from direct taxation identified that it is possible for tax payers to make evasion, because people in the higher income groups do not reveal their full income. They do not hesitate to fill up false returns.

One advantage of indirect taxes is the solution to the problem of externality, because increases in indirect taxation will push up prices, decrease consumption and hence reduce the effects of negative externalities such as damage to the environment. Furthermore, indirect taxation gives the government more control over its use of fiscal policy because indirect taxes can be changed between budgets without parliamentary approval. In contrast, direct taxes can only be changed in the annual budget. But disadvantages from indirect taxation identified that it is inequitable because since each individual pays the same rate on their purchases, the poor pay a larger proportion of their incomes.

\section{1- Pubic Finance ; Expenditures and Revenues}

The financing of Government is important and universal concern. Governments in the most of the world have started number of public projects, such as social security, protection and other services of public utilities like electricity, water supply, railways, atomic energy, etc. Furthermore, the Government provides social amenities in the form of education, health care and public utilities. For all these expenditures Government 
requires adequate revenue. The total amount of expenditures and revenues of a Government are much larger than the revenues and expenditures of a single man within the country.

Therefore, public finance deals with the income and expenditures of public athourities. It deals with the financial operations or finances of the Centeral Government, State, Regional and Local governments revenues from various tax sources and non-tax sources, such as revenue from public service sector in the economy or from borrowing from individuals. The Government raises revenue from internal as well as external sources to incure huge expenditure on various functions the Government has to perform like; law and order, defence, economic development. Thus public finance is concerned with the use and accomplishment of monetary resources of the Government. In fact, Public Finance deals with how and through what sources the Government gets income and how it spends to control and administrate its incomes and expenditures. These two activities; rising of revenue through taxation and other sources, and spending it on various services, together constitute"Public Finance".

\section{1-1 Public Expenditure}

Public expenditure is issued by public authorities; central state and local governments, either for the satisfaction of collective needs of the citizens or for promoting their economic and social welfare. It is not only the most important but also the central part of the study of public finance, which incurred by the Government for attainment of public good. Every Government has to maintain law and order armed forces for providing protection, public parks, schools, and health care of people. Furthermore, Government has to perform certain welfare measures like maternity protection, arranging for cheap food, cloth and low-cost housing for poor people. All multifarious activities that are increasing every year require huge funds. Public expenditure, thus occupies the same important place of public finance that consumption occupies in the study of economics.

Alka Gupta (2002) stated that, the aims of public expenditure are two parts:

(i) Security of life against the external aggression and internal disorder and injustice.

(ii) Development or up gradation of social life in the community.

1-The public authority works in different ways for the benefit and welfare of the people. The Government organizes the generalized services like public health and education and the whole society benefited by these function of the State.

2-By using the public expenditure, the Government influences directly or indirectly, the industrial and commercial system of nation, thereby helps towards the economic and social development of the society. Furthermore, public spending should be designed to optimize the level of investment in such a way as to maintain full employment with growth.

\section{1-2 Public Revenue}

Public revenue is necessary for the Government to perform its various functions for the welfare of the society. It holds the same position in the study of public finance, which production holds in the study of economics. The importance of raising public revenue follows from the necessity of incurring public expenditure. As the modern Government has to perform several functions for the welfare of the people and like these functions require huge amount of expenditure, which can be financed only through public revenue. Alka Gupta defined "Public Revenue" in a broad and a narrow sense, it includes all the income and receipts which the Government happens to get during and period of time.

Public revenue includes income from taxes, prices of goods and services supplied by public enterprises, revenue from administrative activates, such as fees, fines, gifts and grants while public receipts include all the incomes of the government that it may have received during a given period. In the narrow sense, it includes only sources of income of government, which described as "revenue resources." The sources of public revenue coming from:

1- Tax revenue

2- Non tax revenue

Governments will play an important roe in the socio-economic development of society; social development may be in form of raising the level of living and social welfare in the form of providing social amenities to the people. Social amenities are in the form of education, health care sanitation utilities like electric supply, water supply and recreation facilities. Economic development involves two aspects:

(i) Economic growth in the form of raising the level of per capita income.

(ii) How best the income raised and distributed among workers and other sections of society, which involved in the process of production.

Income in every society is generated from three important sectors, they are:

1- Agricultural sector 
2- Industrial sector

3- Tertiary sector that includes trades, banks, insurance companies and services.

In order to optimize income from these sectors, the Government plays an important role in removing the problems faced by the people in each of these sectors by providing financial and other types of support.

One of the most important resources of revenue for every Government is Tax. In the past, payment of taxes was optional; a choice was given to the people to pay the tax and to avail the benefit of social amenities in the form of education health care and sanitation. But now, tax payment became a compulsory contribution by every citizen to Government to enable the Government to fulfill its commitments towards society. Every Government imposes two kinds of taxes:

1- Direct taxes

2- Indirect taxes

\section{THE IMPORTANCE OF THE TAXATION AS A PUBLIC REVENUE}

In both developed and developing countries, governments collect taxes to fund public services. Although many developing countries are highly dependent on foreign aid, taxes are the principal own-revenue source. Other own-revenue sources are non-tax revenue, which includes fees, licenses, mineral rights, etc., and capital revenue, which includes income from sales of government assets, including privatizations. Since taxes are the principal source of recurring revenue under government control, in all countries tax policy is at the heart of the political debate on the level of public services that should be provided and who should pay for them. The resolution of the debate varies by country and within countries over time. In democratic countries, the resolution depends on the ability of political parties, factions and interest groups to influence policy decisions and to influence voters to support these decisions. Groups without political or economic power, such as the poor and women, are often excluded from this debate and from tax policy decisions.

\section{EFFECTS OF TAXATION}

Taxes have macro and micro ecnomic effects in a modern economy. The economic effects of taxation may be good as well as bad. Due to heavy imposition of tax, the ability of tax -payer to work may be affected adversely or he may be reluctant to work more since his additional income is taxed. This is turn, may affect production adversely. There are also direct and indirect effects on the distribution of income. Taxation also affects the allocation of production and income of the community. Such changes caused by different taxes have far-reaching effects on the economic welfare of the society. Therefore, the government should not keep only revenue consideration in mind but the economic effects of taxation should also be considered.

Economics is concerned with the production and distribution of wealth. Taxation has either direct or indirect effects on almost every aspect of production and distribution in modern economies and is therefore an important aspect in economic research. Economic efficiency is about maximizing economic output given the resources available to the community. This is not just maximizing production but also producing the goods and services that consumers value most. It is possible to show that, in certain circumstances, markets are economically efficient. If a tax distorts an otherwise efficient market this is known as the excess burden of taxation, which means the extra economic cost imposed on the community because taxes have caused people to make economic decisions they would not otherwise have made.

Simon James (2007) stated that, the effects of taxation on work effort, or labor supply, has generated a huge amount of research. When an income tax is increased, this reduces the net financial return to work and individuals might substitute other activities or leisure for paid employment - and this is known as the substitution effect. On the other hand, a tax increase would make individuals worse off and therefore that might make them work harder to maintain their incomes - the income effect. The overall effect of taxation on labor supply is therefore an empirical question and has been subject to very large numberof investigations. The effects of taxation on saving have also received a considerable amount of attention. Only through saving can economic resources be released for capital investment and the rate of saving can affect the level of economic activity by influencing the aggregate level of demand.

Investment is also important and requires enterprise and a willingness to take economic risks. Some of the findings here may be unexpected. Profits from enterprise usually taxed but losses may also normally be set against profits in calculating taxable income. The government can therefore find itself as a sort of sleeping partner, sharing in both profits and losses of enterprise. In such circumstances researches shown that the overall amount of economic risk-taking could actually increase following an increase in tax. Stiglitz (1969) has analyzed this further. The government has to play a major role in exploiting the capacity to invest of the taxpayer by adopting an appropriate tax policy. The government should exempt earnings from investment to encourage savings and capital formation.

\section{TYPES OF TAXES}


Taxes are classified according to the point, which they are paid, and by who is paid. Direct taxes are paid to the Inland Revenue by the individual taxpayer according to whom the tax is levied. Indirect taxes are paid by the consumer according to the goods that they are purchased; the taxes are collected by the firms and repaid to the government. Here are main types of taxation:

\section{1- Taxation of income and wealth}

These are direct taxes on households. There are problems for measurements which reduce the effectiveness of these taxes because it is hard to calculate income for groups such as the self employed in small enterprises where salaries are not paid and it is difficult to distinguish between revenue, operating profits and income. Taxing wealth even more difficult, because there are assets maybe unique and there is no share price to indicate value.

\section{2-Taxation of goods and services}

There are indirect taxes levied on expenditure by households; the revenue collected by firms and repaid to the government. It is easier to manage expenditure tax than income and wealth taxes because there are fewer problems associated with measurement. However, the black economy remains and not all-economic transaction appear in accounting. Higher tax levied on those with greater levels of expenditure, but it is not fair because the average rate of tax is higher for those on low incomes because they allocate higher proportion of their income to expenditure on goods.

\section{3-taxes on organizations}

These are mostly taxes on firms. Firms are taxed according to their income and the level of their profits; they are also taxed according to their use of factor of production such as labor and energy. It is possible to say that governments never actually tax firms, because firms directly pas on any taxes to consumers. In the end most firms are owned by domestic peoples who themselves are liable for the tax on households and firms benefit coming from public expenditure.

\section{DIRECT TAXATION AND CONSUMER}

Direct taxation is defined as taxation imposed upon the person who is intended to be the final bearer of the burden of payment. Today's income tax is a form of direct taxation, which is to say the government levies the tax directly on individuals and businesses. The income barely affected anyone. Sales taxes, means we are agreeing to pay them by purchasing the item that is being taxed. Sales taxes are levied upon a business activity, not upon individuals or businesses directly. You determine how much you buy and you control how you spend your money. Maintaining an income tax or any direct tax on citizens has the effect of instituting an organization of government policy whose charge is to constantly review your bank accounts and your finances, leaving you alone only so long as you keep paying. You are in effect, paying the government for protection from your government.

\section{ADVANTAGES OF DIRECT TAXATION:}

1- Equitable: direct taxes such as income tax, taxes on property, capital gains tax are equitable because they are based on the principle of progression. Higher incomes are taxed more heavily and lower incomes slightly, the larger the income the higher the rate of taxes. Direct taxes are taxed according to the ability to pay by the tax payers and the ability to pay is interpreted as the money income of the assesses which means any person having a flow of income is expected to pay tax. Taxes at high rate are paid by the richer section of society and lower are paid by the poorer section of society.

2-Certainty: direct taxes satisfy the condition of certainty which involves the rate of taxes, such as income tax which are publicized. In other words, the tax payer is certain as to how much he is expected to pay, and similarly the state is certain as to how much it has to receive income from direct taxes. There is also certainty about the time of payment and manner of payment. Therefore, tax payers can plan their own budgets and other economic activities in advance they know with certainty their tax liabilities.

3-Reduce inequalities: direct taxes are progressive in nature, and rich people are subjected to higher rates of taxation, while poor people are exempted from direct tax obligations. Rates of taxes increase as the levels of income of persons rise. As they fall heavily on the rich, they take away a large part of their income by way of income and property taxes and the revenue collected is used for providing social amenities like food, clothing and housing facilities to the poor people. The real income of the poor rises and that of the rich falls. Therefore, direct taxes help to reduce inequalities in incomes and wealth.

4-Elasticity: elasticity in indirect taxes implies that more revenue is collected by the government by simply raising the rates of taxation. In other words, revenue of government may be increased by increasing the incomes 
of the people. Therefore, the income of the government from direct taxes may increase with the increase in the incomes of the people.

5-Civic consciousness: direct taxes in calculate the spirit of civic responsibility among the tax payers. Since, direct taxes are certain the tax payers feel the pinch of such payment and are alert and take keen interest in the method of public expenditure, weather the revenue raised is properly utilized or not. In other words, people try to be vigilant about how much tax revenue is being raised by the government and to what uses it is being put. Tax payers become conscious of their rights and obligations. In a democratic country, this civic consciousness checks the wastage in the public expenditure.

6-Adverse effects of direct taxes can be avoided: one of the merits of direct taxes is that their rates can be modified in time to avoid their adverse effects on willingness and ability to work, save and invest. In other words, reasonable rates of income tax, property tax may avoid adverse effects of direct taxes on tax payers. Exemptions and concessions may also avoid their adverse effects on production.

\section{Disadvantages of direct taxation:}

Direct taxes are not free from disadvantages; they are criticized in the following grounds:

1-Unpopular: direct taxes are unpopular because they are required to be paid in one lump sum which is inconvenient to the tax payer. Direct taxes are generally not shifted; therefore, they are painful to the tax payer. Hence, such taxes are unpopular and are generally opposed by the tax payers as they have to be born by the assesses themselves.

2-Inconvenience: direct taxes are inconvenient in nature, because tax payer has to submit the statement of his total income along with the source of income from which it is derived. Moreover, direct taxes are paid in lump sum which causes inconvenient to the tax payers.

3-Possibility of Evasion: a direct tax is said to be a tax on honesty, but it can be evaded through fraudulent practices. As stated above, direct taxes are certain and tax payers know the rate of tax they have to pay. Therefore, awareness of tax liability tempts the tax payer to evade tax. It is a fact that the people in the higher income groups do not reveal their full income. They do not hesitate to fill up false returns, concealing a considerable part of their incomes.

4- Arbitrary: direct taxes are fond to be arbitrary because there is no logical or scientific principle to determine the degree of progression in taxation. Rates of income tax and other direct taxes are determined according to the whims of taxation authorities. They are likely to underestimate the taxable capacity of the people.

\section{Indirect Taxation and Consumer}

Indirect taxation is defined as taxation imposed upon others than the person who is intended to bear the final burden. There has been a gradual shift away from direct towards indirect taxes especially in the UK over recent years. Increased indirect taxation has allowed the government to reduce the overall tax burden on income and capital. Both income tax and corporation tax rates have been lowered. Supply-side economists believe that indirect taxes are preferable to direct taxes because they create less of a disincentive to work since employees retain more of what they earn. The argument runs that workers will respond to lower marginal tax rates by expanding the hours they work and raising productivity.

There are two effects from a tax change from direct taxes to indirect taxes; the substitution and the income effect.

1- Substitution effect: when income tax rates are cut the return to working extra hours rises. This means the opportunity cost of leisure time is higher than before.

2- Income effect: when tax rate are reduced, people can earn a particular "target" post-tax income with fewer working hours than before the tax cut. If they regard leisure as a normal good, they may prefer to switch out of work and enjoy more leisure time whilst still earning the same income.

In the comparison between these two effects the results of research are ambiguous, one group where increased indirect taxation and reduced direct taxation might improve incentives are households who affected by the poverty and unemployment traps. People in low paid jobs and the currently unemployed may have little incentive to take paid work or work extra hours if the net financial benefit of doing so is very small. Extra income may be subject to income tax and national insurance and means-tested benefits may be withdrawn as additional income comes in from working. Lower starting rates of income tax may provide a better incentive for low-paid workers to enter the active labor market. The Labor Party has brought in a $10 \%$ starting rate of tax and has also introduced the working families' tax credit as part of a strategy to boost the post-tax incomes of families in poorly paid jobs.

\section{Advantages of indirect taxation:}


1-One advantage of indirect taxes is that they can be used explicitly to correct for market failure caused by environment damage. Indeed governments across the world are coming to the view that indirect taxes can be used more intensively to meet environmental objectives.

2-The use of indirect taxation is one solution to the problem of externality: the producer or consumer is charged the full social cost and demand will respond accordingly. Environmental economists argue that the most effective way to protect the environment from carbon dioxide and other energy-linked pollutants is to tax the pollute.

Indirect tax increases will push up prices, decrease consumption and hence reduce the effects of negative externalities such as damage to the environment. However, there is a danger that using green taxation to influence demand will damage specific industries. For example, the high rate of taxation on alcohol sold in the UK, as opposed to continental Europe, has badly affected UK drink industries. A huge trade in importing alcohol has grown up, resulting in many jobs being lost in the UK.

Indirect taxation gives the government more control over its use of fiscal policy. In theory, certain indirect taxes can be changed between budgets without parliamentary approval. In contrast, direct taxes can only be changed in the annual budget.

\section{Disadvantages of indirect taxation:}

An important argument against indirect taxes is that they tend to be regressive. Since each individual pays the same rate on their purchases, the poor pay a larger proportion of their incomes in indirect taxes (in comparison with direct taxes which tend to be progressive and are seen as more equitable - the proportion of income paid in taxes rises as income rises when a tax is progressive). An example of this in the UK is the high level of duty on tobacco products. Evidence from the Office of National Statistics shows, which the duty on tobacco takes up a much larger percentage of the disposable incomes of lower income groups.

\section{CONCLUSION}

One of the most important resources of revenue for every Government is tax; tax payment became a compulsory contribution by every citizen to Government to enable the Government to fulfill its commitments towards society. In all countries tax policy is at the heart of the political debate on the level of public services that should be provided and who should pay for them. Taxation has either direct or indirect effects on almost every aspect of production and distribution in modern economies and is therefore an important aspect in economic research. Taxes are classified according to the point, which they are paid, and by who is paid. Direct taxes are paid to the Inland Revenue by the individual taxpayer according to whom the tax is levied. Indirect taxes are paid by the consumer according to the goods that they are purchased. Direct and indirect taxation have different impacts on the consumer, they have advantages and disadvantages in the same time.

Direct taxation is equitable for consumers because higher incomes are taxed more heavily and lower incomes slightly. Furthermore, direct taxes satisfy the condition of certainty because tax payer is certain as to how much he is expected to pay, and similarly the state is certain as to how much it has to receive income from direct taxes. Disadvantages from direct taxation identified that it is possible for tax payers to make evasion, because people in the higher income groups do not reveal their full income. They do not hesitate to fill up false returns.

One advantage of indirect taxes is the solution to the problem of externality, because increases in indirect taxation will push up prices, decrease consumption and hence reduce the effects of negative externalities such as damage to the environment. Furthermore, indirect taxation gives the government more control over its use of fiscal policy because indirect taxes can be changed between budgets without parliamentary approval. In contrast, direct taxes can only be changed in the annual budget. But disadvantages from indirect taxation identified that it is inequitable because since each individual pays the same rate on their purchases, the poor pay a larger proportion of their incomes.

\section{REFERENCES}

[1] Alka Gupta, Public Finance and Tax Planning, 2002.

[2] Caren Grown What Gender Equality Advocates Should Know about Taxation, 2006.

[3] Emmanuel Saez, Direct or Indirect Instruments for Redistribution, 2002.

[4] Helmuth Cremer, Direct versus Indirect Taxation: The Design of the Tax Structure Revisited, 2001.

[5] Simon James, Taxation Research as Economic Research, 2007.

[6] Stiglitz, J. 'The Effects of Income, Wealth and Capital Gains Taxation on Risk-taking' Quarterly Journal of Economics, 1969.

[7] S. Connolly and A.Munro, Economics of Public Sector, 1999. 